\title{
On the presence of the alien exotic sap beetle Phenolia (La- siodites) picta (Macleay, I 825) (Coleoptera Nitidulidae) in Italy
}

\author{
Ignazio Sparacio', Angelo Ditta ${ }^{2}$ \& Salvatore Surdo ${ }^{3^{*}}$ \\ 1Via Principe di Paternò 3, 90144 Palermo, Italy; e-mail: edizionidanaus@gmail.com \\ ${ }^{2}$ via Trieste 16, 91026 Mazara del Vallo, Italy \\ ${ }^{3}$ Department of Agriculture, Food and Forest Sciences, University of Palermo, Viale delle Scienze, Edificio 4, 90128 Palermo, \\ Italy \\ *Corresponding author, e-mail: salvatore.surdo@unipa.it
}

\begin{abstract}
The exotic sap beetle Phenolia (Lasiodites) picta (W.S. Macleay, 1825) (Coleoptera Nitidulidae) is an alien species recently recorded in Europe (Spain, France, and Greece), and Turkey. For Italy, only a single record of $P$. cf. picta is reported from Sicily. In this paper, we studied this specimen confirming the presence of $P$. picta in Italy.
\end{abstract}

KEY WORDS Alien species; Phenolia; Nitidulidae; Sicily.

Received 02.12.2019; accepted 12.03.2020; published online 29.05.2020

\section{INTRODUCTION}

The problem of alien species has always been present in past centuries and has been linked to the various activities of man on our planet. However, in recent decades this phenomenon has multiplied and, often, has become detached from the presence of man, following its own dynamics and characteristics that are not always easily understood and have a great environmental impact.

Insects are one of the groups most affected by this phenomenon and there are now numerous reports of these invasive species in Europe (Roques et al., 2009). Among the Coleoptera, the Nitidulidae family includes numerous species introduced in Europe and in the Mediterranean area (Jelinek et al., 2016).

The nitidulid genus Phenolia Erichson, 1843 is the one that presents a wider distribution with two species listed also in Europe: P. tibialis (Boheman, 1851) and P. picta (W.S. Macleay, 1825) (see Jelínek et al., 2016).
Particularly, P. picta has been introduced into Spain, France, Greece, and Turkey (Jelinek \& Audisio, 2007; Vinolas et al., 2014, as Phenolia limbate tibialis; Montagud \& Orrico, 2015; Jelinek et al., 2016; Kalaentzis et al., 2019) (Fig. 1). Currently, there are no record of this species in Italy, except for the online reporting of a specimen of $P$. cf. picta sampled in Sicily (Ditta, 2019).

In this paper, we report the study of this specimen that allowed us to identify it as P. picta and, therefore, to confirm the presence of this species in Sicily and Italy.

\section{RESULTS}

\section{Systematics}

Ordo COLEOPTERA

Subordo POLYPHAGA Emery, 1886

Familia NITIDULIDAE Latreillae, 1802

Subfamilia NITIDULINAE Latreillae, 1802 
genus Phenolia Erichson, 1843

Subgenus Lasiodites Jelínek, 1999

Phenolia picta (W.S. Macleay, 1825)

EXAMINED MATERIAL. Italy, Sicily, Mazara del Vallo, near gorgo Basso of the Riserva Lago Preola, 2.XI.2019, 1 male, legit A. Ditta.

DesCriPTION. Male (Fig. 2). Length $7.4 \mathrm{~mm}$; maximum width (at the base of the pronotum) 4.1 $\mathrm{mm}$. Dark brown in colour with the light yellowish elytral band formed by the union of some of the light small elytral spots, distinctively bicoloured femora (light and dark brown). The posterior pronotal angles not projecting backwardly. Pro- and mesotibiae sub-rectilinear, not sinuate. Aedeagus as in figure 3 .

Distribution And Biology. Phenolia picta is an invasive species with Oriental and Palaeotropical area of origin. It is widespread in Madagascar, Mau- ritius, Nosy Be, Reunion, and Seychelles, Australian and Indomalayan regions, eastern Palaearctic zone (including Korea, China, Japan, and Pakistan), Hawaii, and is probably also present in Polynesia (Montagud \& Orrico, 2015). In Europe and Mediterranean areas, it has been introduced into Spain, France, Greece, and Turkey (Jelinek \& Audisio, 2007; Vinolas et al., 2014, as Phenolia limbata tibialis; Montagud \& Orrico, 2015; Jelinek et al., 2016; Viñolas \& Muñoz Batet, 2017; Kalaentzis et al., 2019).

Phenolia picta lives exclusively on fruits in the advanced stage of maturity that have already fallen to the ground (Marthur et al., 1958; Delobel \& Tran, 1993; NZS Bio Pineapple Th., 2001; Abdullah \& Shamsulaman, 2008; Hishike et al., 2009; Naka et al., 2010).

Montagud \& Orrico (2015) have conducted interesting observations on the biology of this species in Spain which they found in nature on the ripe and fallen fruits of fig (Ficus carica), prickly pear ( $O p$ -

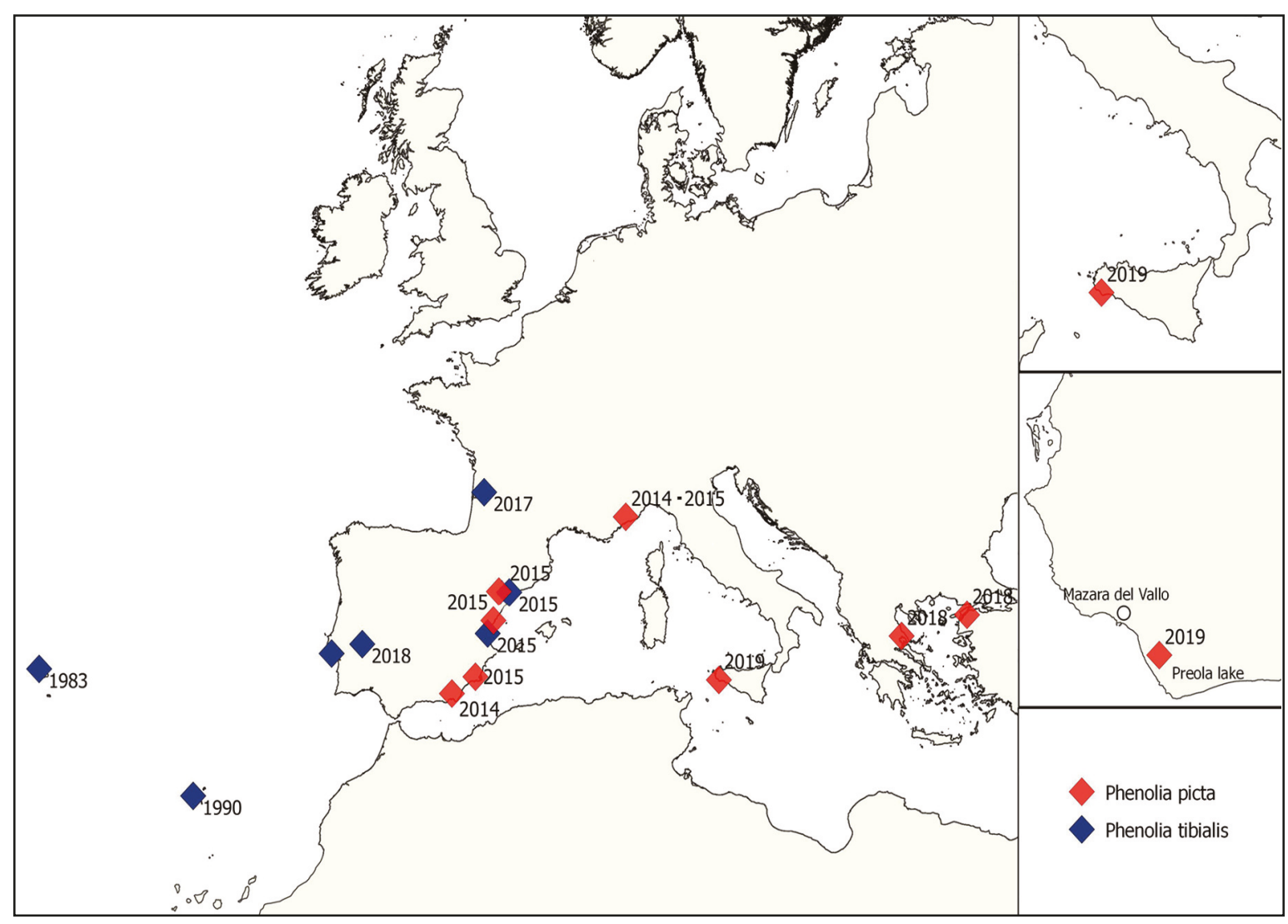

Figure 1. Map showing previous published records of Phenolia (Lasiodites) picta and P. (Lasiodites) tibialis in Europe and Turkey (see text), and our new record of the species in Italy. 


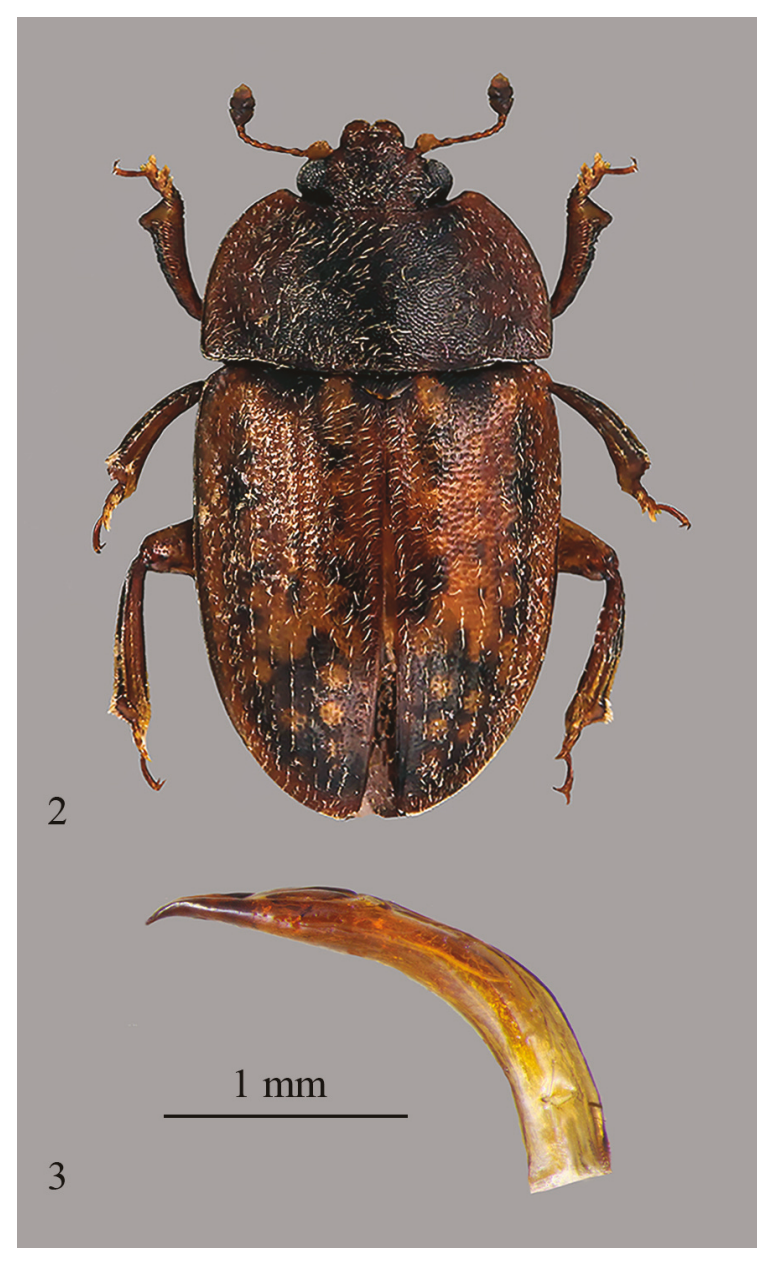

Figures 2, 3. Phenolia (L.) picta male from Sicily, length 7.4 mm. (Fig. 2), with aedeagus (Fig. 3).

untia sp.), vine (Vitis vinifera), and oranges (Citrus sp.). These authors observed $P$. picta and $P$. tibialis living in different locations and managed to breed them in the laboratory by making further observations on their biology and larval morphology.

Introduced populations of $P$. picta have been observed to coexist with other native species of nitidulids in several localities (Viñolas et al., 2014; Montagud \& Orrico, 2015).

Remarks. Phenolia picta is very similar to $P$. tibialis, other alien species recently introduced into Europe but not reported from Italy (Jelinek et al., 2016). Phenolia tibialis has the very transverse pronotum covered by strong and dense punctuation with broad base and posterior pronotal angles moderately projecting backwardly, darker elytra with aligned bristles, pro- and mesotibiae strongly sinu- ous in their distal part in the male, aedeagus with the apex of the parameters shorter and less pointed.

\section{ACKNOWLEDGEMENTS}

We want to thank Marcello Romano (Capaci, Italy) for the aedeagus photo.

\section{REFERENCES}

Abdullah F. \& Shamsulaman K., 2008. Insect Pests of Mangifera indica Plantation in Chuping, Perlis, Malaysia. Journal of Entomology, 5: 239-251.

Delobel A. \& Tran M., 1993. Les Coléoptères des denrées alimentaires entreposées dans les règions chaudes. In: Faune tropicale. Orstom Éditions, pp. 424.

Ditta A., 2019. Phenolia picta (MacLeay, 1825) (cf.) Nitidulidae. http://www.entomologiitaliani.net/public/forum/phpBB3/viewtopic.php? $\mathrm{f}=281 \& \mathrm{t}=86401$ \&sid=f45658c1ff4f8d67b3d050743b68b603

Hishike M., Yukimori A. \& Mitsui N., 2009. Integrated control of Lasiodactylus pictus (MacLeay) attacked Japanese apricot by cultural control and water dipping method. Bulletin of the Wakayama Research Center of Agriculture, Forestry and Fisheries, 10: 27 33.

Jelínek J. \& Audisio P., 2007. Family Nitidulidae. In: Löbl I. \& A. Smetana (Eds.), Catalogue of Palaearctic Coleoptera. Elateroidea, Derodontoidea, Bostrichoidea, Lymexyloidea, Cleroidea, Cucujoidea. Apollo Books, pp. 459-491.

Jelinek J., Audisio P., Hajek J., Baviera C., Moncoutier B., Barnouin T., Brustel H., Genç H. \& Leschen R.A.B., 2016. Epuraea imperialis (Reitter, 1877), new invasive species of Nitidulidae (Coleoptera) in Europe, with a checklist of Sap Beetles introduced to Europe and Mediterranean areas. Atti della Accademia Peloritana dei Pericolanti. Classe di Scienze Fisiche, Matematiche e Naturali, 94: 1-24.

Kalaentzis K., Mpamnaras A. \& Kazilas C., 2019. First record of the alien exotic sap beetle Phenolia ( $\mathrm{La}$ siodites) picta (Coleoptera: Nitidulidae) in Greece. Entomologica Hellenica, 28: 11-16. doi: https://doi. org/10.12681/eh.21323

Kirejtshuk A.G. \& Kvamme T., 2002. Revision of the subgenus Lasiodites Jelínek, 1999, stat. nov. of the genus Phenolia Erichson, 1843 from Africa and Madagascar (Coleoptera, Nitidulidae). Mitteilungen aus dem Museum für Naturkunde in Berlin, Zoologische Reihe, 78: 3-70.

Montagud S. \& Orrico M.A.I., 2015. Dos especias exoticas del genero Phenolia Erichson, 1843 (Coleoptera, 
Nitidulidae) en la peninsula Iberica. Boletin de la Sociedad Entomologica Aragonesa, 57: 351-357.

Mathur R.N., Singh B. \& Lal K., 1958. Insect Pests of Flowers, Seeds and Fruits of Forest Trees. Indian Forest Bulletin (N. S.), 223: 1-105.

Naka K., Yukimori A., Hishike M. \& Mitui S., 2010. Cultural control of Lasiodactylus pictus (Macleay) atacked Japanese apricot by water diping method. Bulletin of the Wakayama Research Center of Agriculture, Forestry and Fisheries, 11: 45-52.

NZS Bio Pineapple Th. 2001. Importing Fresh Fruit/Vegetables - Pineapple (Ananas comosus) from Thailand. MAF Biosecurity Authority, $17 \mathrm{pp}$.

Roques A, Rabitsch W., Rasplus J.Y., Lopez-Vaamonde
C., Nentwig W. \& Kenis M., 2009. Alien terrestrial invertebrates of Europe. In: Handbook of alien species in Europe. Springer, pp. 63-79.

Viñolas A. \& Muñoz Batet J., 2017. Noves aportacions al conèixement de la fauna coleopterològica de la península Ibèrica i illes Balears. Nota 2a (Coleoptera). Butlletí de la Institució Catalana d'Història Natural, 81: 177-184.

Vinolas A., Munoz-Batet J. \& Soler J., 2014. Cita de Phenolia (Lasiodites) limbata tibialis (Boheman, 1851) para Espana (Coleoptera: Nitidulidae), y de otros coleopteros nuevos o interesantes para Cataluna. Bulleti de la Institucio Catalana d'Historia Natural, 78, 109-114. 